Lionel Tiger (London School of Economics). Writing of doctoral dissertation on the Ghana Civil Service (London).

Merwin Crawford Young (Harvard). Writing of doctoral dissertation on the structure and functioning of political and administrative institutions in the Republic of the Congo (Harvard).

Alvin Zalinger (Columbia). Writing of doctoral dissertation on educated Nigerians and their status (United States).

The following have been awarded fellowships for African studies at American universities:

Victoria Helen Bomba (Wisconsin). Intensive Arabic language training, training in field methodology, and completion of all requirements for the Ph.D. degree except the dissertation (Wisconsin).

Frederick Charles Gamst (Berkeley). Programme of area studies relating to Africa in anthropology, history, and political science and Amharic language training (Berkeley).

Nicholas Snowden Hopkins. Programme of African area studies (United States).

Raymond Kent. Programme of African area studies with emphasis on history (Wisconsin).

Frank Andrew Kunz (McGill). Programme of interdisciplinary studies relating to Africa (United States).

Inez Virginia Smith (Yale). Programme of African area studies and intensive French language training (United States).

\title{
The Centre of West African Studies at the University of Birmingham
}

A CENTRE of West African Studies has recently been established at the University of Birmingham. The Director is Dr. J. D. Fage, formerly Lecturer in History at the School of Oriental and African Studies in the University of London and Professor of History in the University of Ghana, who has been appointed as Professor of African History. The purpose of the Centre is to provide a firm nucleus within the university for the study and teaching of the ethnography, geography, history, sociology, economics, law, government, and languages of West Africa. In order to make the best use of the resources initially available, it is proposed that the Centre shall first concentrate its attention, more especially in research, on the eastern half of West Africa. The Director intends to make it his responsibility to establish the closest possible relations between the Centre and universities and other learned institutions in Nigeria, Niger, Dahomey, Togo, Ghana, Volta, and the Ivory Coast.

\section{The Scandinavian Institute of African Studies}

THE Scandinavian Institute of African Studies was established at the University of Uppsala on I September I 962 . It is part of the University but has its own board of governors and its own budget. It will be formally organized from I July I 963 . The Institute works in close contact with the Library of the University which has a large collection of literature on Africa. One of its immediate aims is to compile lists of books and other material concerning Africa or African problems in Scandinavia which are also to be kept available for reference. From 1962 the Institute is publishing a series of pamphlets in Swedish on African countries and territories and also plans a series of practical handbooks for beginners on some major African languages. A bulletin in French and English will be issued by the Institute, containing bibliographies, teports on Scandinavian research in connexion with Africa, papers on African problems, \&c. Lectures by specialists on Africa are being arranged and the Institute plans to give special courses and organize seminars on contemporary African problems. 